Dossiê: Ordens Religiosas Medievais: Poder e Sociedade - Original Article (c) (i)

\title{
Sanctity in the Order of the Preachers: Friar Bartolomeu dos Mártires and the tridentine model for episcopal authority (XVIth-XVIIIth centuries)
}

\author{
Santidade na Ordem dos Pregadores: Frei Bartolomeu dos Mártires \\ e o modelo tridentino de autoridade episcopal (séculos XVI e XVII)
}

Juliana Torres Rodrigues Pereira*

\begin{abstract}
Bartolomeu dos Mártires, O.P., Archbishop of Braga (1559-1582), became an important character to the Order of the Preachers as a model of the new archetype of episcopacy consolidated during the last period of the Council of Trent (1562-1563). Due to his protagonism in the tridentine debates, his published treatises about the episcopal pastorate, his ruling over Braga and his good reputation regarding common ecclesiastical sins, the friar was considered a model to be followed in the post-tridentine Church and soon turned into a candidate for sanctity. Bartolomeu dos Mártires' biographies, written by two of the most important dominicans of the sixteenth and seventeenth centuries, the theologian Luis of Granada and the chronicler Luis de Sousa, indicated the signs of holiness in his characteristics and behavior, reproduced in the canonization process initiated in 1631. However, proposing him as a holy example meant creating a sanctified memory and silencing his several political conflicts and controversies. The aim of this paper is to propose an analysis of the sanctification of Friar Bartolomeu dos Mártires, based on the Archbishop's hagiographies and canonization process as a way to glorify the Order and propagate the pastoral archetype, putting aside his political feature, comparing History and Memory.
\end{abstract}

Keywords: Sanctity, Pastorate, Order of the Preachers, Catholic Reformation.

\section{Resumo}

Bartolomeu dos Mártires, O.P., Arcebispo de Braga (1559-1582), tornou-se um importante personagem na Ordem dos Pregadores como modelo do novo arquétipo episcopal consolidado durante a última fase do Concílio de Trento (1563-1563). Por seu protagonismo nos debates tridentinos, seus tratados publicados sobre o pastorado episcopal, seu governo sobre Braga e sua boa reputação no que diz respeito aos pecados comuns do clero, o frei foi considerado modelo a ser seguido na Igreja tridentina, e logo tornou-se candidato a santo. Suas biografias, escritas por dois dos mais importantes teólogos dos séculos XVI e XVII, o teólogo Luis de Granada e o cronista Luis de Sousa, indicavam os sinais de santidade em suas características e comportamento, reproduzidos no processo de canonização iniciado em 1631. No entanto, propo-lo como exemplo sagrado significou criar uma meória santificada e silenciar seus diversos conflitos e controvérsias políticas. O objetivo deste artigo é propor uma análise da santificação de Frei Bartolomeu dos Mártires, baseada em suas hagiografias e no processo de canonização como forma de glorificar a Ordem e propagar o arquétipo pastoral, deixando de lado seu caráter político, comparando História e Memória.

Palavras-chave: Santidade, Pastorado, Ordem dos Pregadores, Reforma Católica.

Article received on September 01, 2017. Approved on December 26, 2017.

* PhD in History (PPGHS/Universidade de São Paulo). Currently acting as Postdoctoral researcher at PPGHIS/Universidade Federal do Rio de Janeiro. This paper combines the first results of my current research about the sixteenth century Mirrors of bishops, sponsored by CNPq (150790/2017-1), and some of the analysis of my PhD thesis, sponsored by FAPESP (2013/11391-0; 2014/26090-9). País de orgem: Brasil - E-mail: julianatrp@gmail.com

Horizonte, Belo Horizonte, v. 15, n. 48, p. 1394-1422, out./dez. 2017 - ISSN 2175-5841 


\section{Introduction}

Friar Bartolomeu dos Mártires was one of the most celebrated characters in the Tridentine Reform scenario, which turned him into an important instrument in the edification of a certain memory of the Order of the Preachers soon after his death. Subject of popular devotion due to his dedication to the people of the Archbishopric, widely known for his effort to impose the tridentine reform among his people, he was the perfect icon to glorify the dominicans as disseminators of the new episcopal archetype. Nevertheless, some of his actions were a point of controversy in what regards the construction of a sanctified image, merging religious affairs and political controversies. Therefore, this paper aims to analyze the fabrication of a certain memory about the Archbishop as a cadidate for sainthood by the Order, indicating the gaps between historical sources and the hagiographical reports, transiting between History and Memory in order to understand what was emphasized and what was silenced throughout the centuries to make Bartolomeu dos Mártires a sanit.

Born in Lisbon in 1514, Bartolomeu Fernandes, his baptism name, seems to had been destined for monastic life since his early years, by a modest family which soon invested in his studies so he could profess in a prominent religious Order. In 1528 the young Bartolomeu joined the Order of the Preachers and professed a year latter, taking the name of “do Vale” (the epithet 'Dos Mártires' was taken latter), with good knowledge of latin and grammar, basic requirements to join the dominicans. The familiy's investment and the novice's dedication quickly paid off. While finishing his studies of Arts and Theology, Bartolomeu progressed from apprentice to teacher, moving alongside the studium from Lisbon to the Monastery of Santa Maria Vitória da Batalha, the so called Batalha Monastery. The teaching period ended with his service to the Crown, between 1552 and 1555, when, as an already renowned theologian, he was summoned to mentor D. Antônio, bastard son of the King's brother D. Luis. After a small hiatus as head of the Benfica Monastery, Bartolomeu dos Mártires was designated by D. Catarina, Regent of the Realm, Archbishop of Braga, Primate of Spain, one of the highest offices in the portuguese Church. 
The last sessions of the Council could be considered a mark for the consolidation of a new model of episcopacy. Whether because of the positive decrees that regulated the parameters to discipline the clergy, increasing the bishop's authority over them, or during the inflamed discussions about the origin of episcopal power and the obligations that came with pastoral office, an archetype of prelate was defined. ${ }^{1}$ A model whose origins went back to a critical literature about the ecclesiastical and episcopal behavior of the fifteenth century and would come to life through the examples of tridentine prelates such as Carlo Borromeo and Bartolomeu dos Mártires. According to José Pedro Paiva, the pre-tridentine portuguese scenario was not very different from the rest of Europe, where episcopacy was held as a guarantee of social status and wealth and pastoral responsabilities were neglected by bishops who did not live in their dioceses. ${ }^{2}$ The end of the Council was a sort of culmination of that new archetype, which had Friar Bartolomeu dos Mártires as a symbol (PAIVA, 2006). His actions in Braga (especially his effort to visit all the lands of the Archbishopric several times, something remarkable that distinguishes him from the previous Archbishops of Braga) made him an unparalleled role model for the reformed portuguese episcopacy. 3

The endeavor to implement the disciplinary decrees and fulfill his pastoral duties, the diligence to constantly visit all parts of the Archbishopric and get to know its population and provide for them, both material (by charity) and spiritually (celebrating the mess, preaching, confessing and creating the structure to prepare a well taught clergy that could fulfill the needs of his sheep), not to mention his widely read treatise on the substance and obligations of episcopacy, consecrated him as a role model for the tridentine pastorate. Soon after his death, he was appointed as a sacred example to be followed by his previously superior as Provincial of the Order

\footnotetext{
${ }^{1}$ There are disagreements about the relevance of the tridentine decrees for the new episcopal archetype. While for Alberigo (1987), the decrees didn't help developing a theory for the episcopate, Oliver Logan (1995) criticized that statement, arguing the outlines of pastorate are indicated in the canons.

${ }^{2}$ A good example of that tendency was Cardinal D. Henrique, who was Archbishop of Braga from 1533 to 1540, amongst the many religious offices he occupied over his life. According to Amélia Polónia, who states D. Henrique was a conscious prelate and zealous for the tridentine reform, his political duties prevented him from appropriately residing and fulfilling his pastoral obligations. See: POLÓNIA, 2005.

${ }^{3}$ On the important role developed by the bishops as agents of the Catholic Reformation, see: PALOMO, 2006; GOUVEIA, 2000.
} 
in Portugal, Luis de Granada. A few decades latter, his value as personification of that archetype and inclination to sainthood, increased by popular demand, were instrumentalized in a dominican hagiography and an attempt to canonize the Archbishop.

\section{Luis de Granada's spirituality and the tridentine episcopal archetype}

Besides having been written by dominican friars, the two treatises on Bartolomeu dos Mártires' life don't have so much in common - at least in what regards the main purpose of each of them. While the first one, written by Luis de Granada, focused on Bartolomeu's piety and dedication to pastorate, as a model to be followed, was conceived more as a mirror of bishops than as an hagiography, 4 the later, by Luis de Sousa, had the obvious purpose of creating a sanctified memory of the Archbishop and celebrate him as a candidate for canonization. Of course both served as means of publicizing the virtues of the Order, especially in what concerns the education of the novices and the discipline they were submitted to in the monasteries - an environment that could bring to life great theologians, pious and devoted clergymen, parameters for religious conduct and guidance of souls. Nevertheless, the idea of glorification of the Order seems part of a program in Sousa's hagiography, especially when considering it as a precedent of the chronicle of the Order he began publishing years latter, while Granada wrote a series of small biographies of clergymen he saw as examples for the tridentine Church, as Cardinal D. Henrique, amongst many theological treatises. Sousa, on the other hand, as chronicler of the Preachers, celebrated his profession. And Bartolomeu dos Mártires was the character chosen to represent the greatness and claim the sainthood status of the iberian dominicans. A task initiated by other hands and materialized by him. Thus, the selection of material, the emphasis given to some elements and the meaning applied to them, the elaboration of events and attempt to erase others,

\footnotetext{
${ }^{4}$ The treatise was first published in 1615 in Valladolid by Juan López, Bishop of Monopoli. It was certainly written between 1582, after the Archbishop retired and chose the Viana monastery as home, and 1588, when the biographer died, years before Dos Mártires' death in 1590 .
} 
silencing aspects of his behavior and ideals as Archbishop, expose different views and aims of the two homonym dominicans, even if the later chose to use fragments of the biography written by the former.

Luis de Granada, head of the dominicans in Portugal and confessor of the Queen Regent D. Catarina, played an important role in the nomination of Bartolomeu dos Mártires to Archbishopric. As suggested in the publications analyzed here and sustained by historiographical research, Granada himself was an option for the position, which afterwards was offered to the lisboetan friar by his indication. An attempt of D. Catarina to avoid conflict between the noble families in desire of such a great title. A compromise, according to some historians (PAIVA, 2006, pp. 331-332). The familiarity between them could have been a result of shared experiences in Évora, when Bartolomeu dos Mártires was tutoring D. Antônio in the jesuits school, as mentioned before. Granada's role in the establishment of the Society of Jesus in Portugal and his proximity to the jesuits may have brought them together, what would have resulted in a common spirituality and mysticism. 5

Granada's main goal was to set a parameter for the catholic clergy. Bartolomeu dos Mártires' biography is a Mirror of bishops, shaped as a role model to be followed, more than a set of positive rules, as this literary gender was usually conceived. His aim was to inspire by example. Immersed in the common tendency of returning to a utopian past, reinforced by the Protestant Reform, his proposal was to go back to a primitive christianism, the age of the Church Fathers who inspired Bartolomeu, a time deprived of the corruption and bad behavior of priests and dignities, when the apparatus and social status of the clergy were not appointed as essential for putting an end to the malice and pride of men and making them obey to the laws of Christ. Thereby, he intended to point virtue as the only possession necessary to guide the flock, using the Archbishop of Braga as an example of efficient

\footnotetext{
${ }^{5}$ That ideia was already indicated by Giuseppe Marcocci (2009).
} 
clergyman without noble status or temporal power. ${ }^{6}$

The clergy's battle against the vices of the world and the flash emerge in several parts of the treatise. Bartolomeu's choice to profess is depicted as an attempt to withdraw the body from the danger and ties of human relations. One of the key concepts, both in Granada's mirror and in Sousa's hagiography, was humility. First of all, humility and frugality in his own house, from the structure and lack of comfort he lived in, his feeding, restricted to the extremely necessary, to the number of servants in his house. His clothes were old ones made of wool and not linen. He fasted and reduced his meat consumption to spare more food for the poor. In Granada's words, punish the flash to subject the spirit. His life in Braga was depicted as reduced to an essential minimum, always indicating the incomes and the wealth of the Archbishopric were destined to those he believed to be their true owners: the people. God was the lord and manciple of the Church, and all its richness should be given to the poor.

The apex of his modesty was the claimed refuse to the position of Archbishop. By alleging incapability of fulfilling the task of guiding his sheep and arguing not being good enough for the position, he would be defining himself as humble and fearful before God against all those who held clerical offices out of greed and didn't comply with their obligations. ${ }^{7}$

An exception to that humbleness was exactly the possibility of displaying and making use of the title of Pirmate of Spain. According to Granada, the will to entitle himself as holder of that privilege was an attempt to celebrate the greatness of his Church. Not making use of it would mean jeopardize or even diminish the status of the institution conceded by Rome, what could justify the claim for the title by a candidate for sainthood - not pride, but a will to respect the position of his See. It is

\footnotetext{
${ }^{6}$ This preamble can also be found in Granada's other Mirror of bishops, De officiis et moribus episcoporum (GRANADA, 1999).

${ }^{7}$ As Foulcault indicated in his analysis of the pastorate, the initial refusal to the nomination was one of its main characteristics. Although his thoughts on the subject are connected to an idea of normalization of social behaviors based on the concept of pure obedience, a questionable assumption, his view of the pastorate as a sort of government can be very useful to analyze the tridentine episcopal archetype (FOUCAULT, 2008, pp. 155-252).
} 
curious how the problem of the Primacy of Spain was indicated by Bartolomeu's decision to use the title when printing the Stimulus Pastorum and not by the discussion about it during the Council of Trent, when the Archbishop fought very hard to be distinguished from the others prelates and vote before them based on that privilege (GRANADA, 1997, pp. 179-180).8

Charity, as the center of the other virtues, was celebrated as one of the dominican's biggest concerns - not limited to sharing and giving the savings of his own income to those in need but also granting the population non-material aid, like dealing with the trade of food in starvation times, or taking the lead of the hospital, providing it with structure and doctors - a good parallel to the metaphor of the episcopal office as a medical one. The representation of the episcopal duties of correcting sins and healing souls in comparison to the job of a doctor who heals the body is a common metaphor in biblical and theological literature and a frequent image in Bartolomeu dos Mártires' writings. And, as it is always reminded in those texts, if spiritual alms are superior to corporal ones, the Archbishop insisted on taking care of his sheep, getting closer to them, correcting their flaws and offering them spiritual fuel through preaching and celebrating the sacraments.

An interesting problem, also connected to the reverberated comparison of the prelate as a doctor, is the consolidation of a memory of the Archbishop as a merciful corrector, bringing his image closer to that of a doctor, or even a teacher, than to the figure of a judge. He did not rectify sins and heterodoxy with rage, censorship and severity, but with zeal and love. Besides, pecuniary punishments were avoided, and excommunication was not an option (GRANADA, 1997, p. 187). 9 His aim was to heal the souls and guide them back into the flock, not cut them off and leave them to the wolves. In Granada's words, those who were corrected by him “ended up amended and not antagonized." (GRANADA, 1997, p. 1875). His mildness or severity depended

\footnotetext{
${ }^{8}$ On the debate about the Primacy of Sapain, see: Letter from the Bishop of Modena to Cardinal Morone. Trent, August 21th 1561 (Archivio Segreto Vaticano, Con. Trid., 42, f. 137); Letter from the Bishop of Modena to Cardinal Morone. Trent, November 13 th 1561 (ASV, Con. Trid., 42, f. 163).

${ }^{9}$ The Archbishop's thought on excommunication were registered on his Mirror of bishops (MÁRTIRES, 1981).
} 
on what he thought would be best for each sheep - which brings us back to the topic of the presence and knowledge of the bishop about his diocesans. Each one would profit more from a certain type of amendment and it was the bishop's obligation to know them all and apply the best medicine to heal the spirits and guarantee that individual would not grow apart from the others on the path towards salvation (Ibid., pp. 186-188). Of course, that kind of attitude in what regards the correction of faith infractions, a liberal behavior that left to the choice of the prelate to silence and treat with kindness serious and scandalous offenses, could be a problem in a realm that held a Holy Office Tribunal. ${ }^{10}$

In spite of that at least ambiguous attitude towards the overlapping of inquisitorial and episcopal jurisdictions, neither Granada nor Sousa mentioned the Inquisition. The Tribunal is left aside, almost as if it didn't exist. Obviously, it wouldn't be productive for his image as a sanctified man to defy the authority of the fight against heresy. But in Bartolomeu dos Mártires' reform program, the authority against heresy and against all sins and threats to the salvation of the flock belonged the pastor.

According to Granada, Bartolomeu dos Mártires expressed even the higher form of charity: love for his own enemies. An episode selected to illustrate this assertion was conveniently explained poorly. The narrative of the attack on the Archbishop during his visit to Viana, when he was called a heretic and a lutheran, conveniently leaves aside the information the turmoil was organized by people connected to the Cathedral Chapter. The decision of not proceeding with an inquiry about it, which certainly should be analyzed as a maneuver in the war between them, was told as an example of his will to forgive even those who made a bad judgment and disrespected him (GRANADA, 1997, pp. 176-177; ADB, Coleção Cronológica, 1941). Political conflicts put aside for the emergence of a sanctified character.

${ }^{10}$ That conclusion was indicatd by Giuseppe Marcocci (2009), and developed by PEREIRA, (2017). 
If charity meant forgiveness for his enemies, for his sheep it meant guidance. Since guaranteeing the salvation of the diocesans should be the main goal of episcopacy, all tasks related to promoting knowledge about the catholic doctrine and access to the word of God were taken very seriously by Dos Mártires, what is indicated by a great amount of documents and depicted by Granada and Sousa. The diligence in implementing the tridentine decrees and approving metropolitan legislation to guarantee the episcopal right to visit the county churches, stricter rules for ordination, the residence of the clergy, the catechism in all parishes of the Archbishopric and a regular celebration of the sacraments were part of the long battle against the Cathedral Chapter, ${ }^{11}$ barely mentioned in Granada's treatise. A conflict full of twists and turns, that both parts sustained until Bartolomeu dos Mártires got the dismissal from office. The final approval of the Provincial Council decrees, after a compromise, and the partial victory in the concords celebrated between them are pointed as an sign of his merciful character, acting with severity only when necessary, and as an example of what a humble bishop, devoted to his sheep, deprived of wealth and trappings, could do.

Another sign of good pastorate and true concern about the sheep was the Archbishop's disposition to correct the sinful clergy, who should set the example of morality, obedience and devotion. Granada insisted on how Bartolomeu dos Mártires didn't let their flaws go unpunished, either these sins were related to bad behavior, usually connected to the sins of luxury, or to not fulfilling ecclesiastical obligations, like celebrating the sacred office regularly or teaching the diocesans the doctrine (ADB, Visitas e Devassas, 47, 435). Besides, the best way to avoid the sins of the clergy and set them as an example of conduct was a proper education. Even more, a better instructed clergy could serve the diocesans in what regarded teaching, preaching and performing the sacraments. The effort to guarantee the foundation of the seminar, according to the tridentine decrees, and the donation of Saint Paul'

\footnotetext{
${ }^{11}$ There is a great amount of documents about the controversy between Archbishop and Chapter clergy in the Districtal Archive (ADB, Gaveta de Concílios e Sínodos: 6, 8, 9, 10, 11, 12, 14, 15, 16, 17, 19, 20, 21, 22; Gaveta das Concórdias e Visitas: 25, 26, 27, 29, 29, 30,31, $32,33,34,35,36,38,39,42,43,45,46,49,51,5254$ 58, 81, 110).
} 
School to the Society of Jesus were an attempt to dispose of a qualified clergy to serve as teachers, preachers and especially confessors, what becomes clear when analyzing the Archbishop's policy regarding the school. ${ }^{12}$ The lack of well prepared clergy in the Archbishopric lead not only to a long term policy of educating those who wanted to be ordained but also to more practical and immediate measures like the printing of doctrine books, among which the Catechism, written to help ministers who did not have enough knowledge of doctrine with an established content to be preached every Sunday and festive days (MÁRTIRES, 1962).

Nonetheless, the political issues in which the Archbishop was involved are silenced in Granada's Mirror. Not only the holy image he intended to build was not that of a pugnacious bishop, engaged in political and privilege conflicts, trapped, then, in the mundane vices of pride and greed, his focus was in humility, charity, piety and devotion. A positive model built from virtues, the three theological virtues - faith, hope and charity. Bartolomeu's spirituality and sense of obligation are the heart of the treatise, not his accomplishments.

A very important element in Granada's biography was his construction of the Archbishop of Braga as affiliated to the mystic tendencies that spread throughout Spain during the sixteenth and seventeenth centuries. A less ruled way to live faith, more connected to the senses and to an individual experience than to tradition. A spiritual trend Granada helped building as part of Juan de Ávila's circle. The inquisitors' perception of the so called alumbradismo as heretic brought him closer to the Tribunal's claws and Granada's decision to migrate to Portugal had a lot to do with that, as it is known. ${ }^{13}$ Hints of that spirituality are spread through the treatise. While praising Bartolomeu's dedication to the study of the Catholic doctrine, Granada claimed his inclination to mystical Theology in addition to Scholastic, dedicating himself to the works of Dionysus, St. Bernard, St. Bonaventure and

\footnotetext{
12 The Archbishop's perception of the classes directed to the instruction of confessor as the most important is obvious in letters exchanged with the School's director: Letter from Tholosa to Borja. Braga, January 5th de janeiro, 1569 (ARSI, Antica Compagnia, Assistentia Lusitaniae, Lusitania, 63, ff. 5-6).

${ }^{13}$ About the alumbradismo, see: PASTORE, 2010.
} 
Gerson. The thoughts on those authors led the Archbishop to write his Compêndio, a compilation of spiritual doctrine, one of his less discussed treatises (MÁRTIRES, 2000). His taste for that kind of reading would have increased after getting in contact with spiritualist people while in Lisbon, where he spent some time after leaving Évora. Dealing with those people, who Granada does not name, since he probably was indicating his own circle, the friar saw the experience of charity as a calling of God. The value of prayer and mortification as pillars to erect what Granada called the "interior man" are widespread through the volume. This would be one of the most important lessons taught to the novices in Benfica Monastery (GRANADA, 1997, p. 158). Without those two elements, fuel to the fire that should come from the the soul, religion became a mask. Some of the images constructed by Granada had the evident goal of getting Bartolomeu dos Mártires closer to that spanish spirituality, such as the indications of a "fire that burned in his heart" (Ibid., p. 158), the celebration of the mass as a way to keep the divine fire alive in the spirit, the use of the time spent on the way from one church to another during visitation periods for prayer and meditation, or the spiritual exercises to which he frequently surrendered himself, vigils, study of sermons and meditation as the expectation to listen to a manifestation of God. Obviously, according to the author, his tendency to self-communion and the practice of spiritual exercises persevered until his last days (Ibid., p. 205). And above all those, one of the final images built by Granada, the memory of an Archbishop who imagined himself soaking Christ's boold up while praying (Ibid., p. 203).

Of course, as a treatise that intended to present the Archbishop as a candidate for sainthood, tales of the supposed miracles he performed are some of the closing arguments (Ibid., pp. 204-205). It is interesting to notice how in both treatises Granada's and Sousa's (SOUSA, 1946, v. 3, pp. 184-192) - the narratives of the miracles he performed are very similar and quickly mentioned only in the end. It is not the ability to perform miracles that defined Bartolomeu dos Mártires as a saint, but his frugal life, his devotion and dedication to pastoral office and charity. Perhaps an attempt to compensate the lack of verifiable miracles that precluded the prelate from being canonized. 


\section{The Archbishop through the ink of the Order of the Preachers}

A few decades after Granada's treatise, the publication of Bartolomeu dos Mártires' hagiography by the Order would indicate a different perspective, leaning towards the Archbishop's actions regarding the pastorate and surveillance of the flock and the asseveration of his jurisdiction. As the memory the dominicans intended to fabricate was focused on his attempt to lead the reform of diocesans and clergy, animosity and conflicts with secular and ecclesiastical authorities became part of the narrative. His dedication to the pastoral duties that distinguished him as a role model for the tridentine bishops was not separated from his quest for authority after all.

The hagiographical treatise, published in 1619, signed by Luis de Sousa, should be considered part of a bigger project, that of a monumental history of the Order of the Preachers, as mentioned above. The life of the great theologian and dedicated Archbishop was a praise to the Order. The treatise, however, was not the result of one man's work. It was Friar Luis de Cácegas who gathered the material and began the writing process in the first place. After his death, in 1616 the task was passed on to Sousa, who carried on with the biography and memorial and became on of the most renowned chroniclers of Modern Europe.

Born in Santarém in 1555, the man baptized as Manuel de Sousa Coutinho only joined the Order of the Preachers after long years of military service and a marriage. His option for a military life and the will to join the Order of Malta occasioned his imprisonment when the ship in which he traveled to the island was captured by moorish. Coutinho lived for a while in Valencia after his rescue and returned to Portugal in 1579, where he got married to a widow of Alcácer-Quibir. It seems to have existed an ancient rivalry between Coutinho and the governors of the Realm, expressed by his attitude of setting fire to his own house in Almada in 1599 so the governors couldn't use it as shelter form the plague that had taken Lisbon. He kept on the move for many years, dedicating himself to several different activities, as 
the book business and colonial commerce, from Madrid to America and back to Portugal. After the death of his daughter, both him and his wife embraced religious life. In 1613 he professed taking the name of Luis de Sousa, and soon was given the task of perpetuating a certain memory of the religion.

Diverging from Granada, Sousa did not hide the Archbishop's conflicts with other authorities - civil or religious - in Braga's territory, but always indicated these disagreements as a cause of sorrow for the biographed, who joined the squabbles to guarantee the honor of his Church and the salvation of the flock, in addition to stating how, despite of all the conflicts, Bartolomeu dos Mártires was respected by his opposers as a pastor and, even more, as a saint man.

The signs of sainthood in his physical and personality are present in the treatise since its very beginning: the birthmark in the shape of a cross in his hand, seen by others only after his death, his gravity and inclination for religion and study since his early childhood, an impulse to leave the world behind and disconnect with the material and mundane life, which would have led him to join the Order.

The comments about the period spent studying and teaching in the dominican monasteries constitute one of the few moments in which Sousa reproduced Granada's speech about Bartolomeu's appreciation for the mystique, contemplation, penance and self-communion (SOUSA, L. op. cit., v. 1, pp. 25-40). This kind of devotion, a faith directed to the interior and to communion with God, as an individual exercise for spiritual improvement, regards almost solely his monastic life. A tendency to isolation, as the best way of communicating with the sacred, expressed also by his supposed dislike to the court, which made him accept his nomination as D. Antônio's tutor with dislike. An image that seems rather unreal when considering his impetus to deal with jurisdictional matters. But when the frame changes and the monk becomes the Archbishop, pastoral activities and charitable work take the center of the hagiography. Prayer and meditation are destined to the care of the flock. These elements only come back to a central position 
in the narrative in the end, after he retired from office and settled in Viana Monastery.

This refusal to get involved in mundane deals, already indicated by Granada, can be linked to another and more important refusal, that of taking over the office of Archbishop. The humbleness of denying his capacity to fulfill the task, his dissatisfaction with receiving the episcopal dignity, along with the lordship and incomes of the Archbishopric complement the tendency to isolation and selfcommunion. The supposed denial made him even more worth it and allowed Sousa the comparison to consecrated models of sanctity, such as Antonino Pierozzi and even Saint Domingos (Ibid., v. I, pp. 51-55), establishing a direct connection between the subject of the hagiography written to glorify the Order and its founder saint.

The abnegation and frugality described in Granada's treatise are also present in Sousa's hagiography. Both insisted on how the Archbishop saved as much as he could, sparing in accommodations, food and service - a simple life, similar to the monastery discipline - to increase the donations to charity.

Another similarity I wish to highlight is the idea of the pastor as a father, who should teach and guide his people with love. Nevertheless, the idea of ruling with love is connected, in Sousa's words, to the intent of good governance of secular and ecclesiastical justice. Mercy, comprehension and the will to amend infractions should be the values guiding the judges. The analogy with the good doctor was used by Sousa as well, but not restricted to the pastorate. The expansion of that principle to the local tribunals was stated in what Sousa claimed to have been Bartolomeu dos Mártires’ policy statement for the Relation Court.

The good doctor heals the ill, and applies all possible medicine before considering cutting a limb (Ibid., v. I, pp. 79-80). Likewise, reprehending and teaching would be more efficient means of correction and guidance towards a sinless life than excluding one individual in error, which would benefit the community, spared from the scandal and bad example, but on the other hand would doom the 
sinner in isolation and no chances of amendment. The pastor does not leave a lost sheep to the wolves, even if it means sacrificing the flock ${ }^{14}$ or his own life. Loosing one of them is as dangerous as loosing all.

Once more, his dedication to preaching was indicated as a way to teach the diocesans about aspects of the doctrine and move them towards devotion and a sinless life. The adaptation of the sermons' content to the public and simplification of the doctrine, using common and clear words, was again indicated as one of his strategies. A new element in Sousa's hagiography is related to its conditions of production. The treatise was written in the baroque culture, it makes sense Sousa wanted to emphasize how the Archbishop tried to move the audience talking about the briefness of life and the terrors of hell in a dramatic e theatrical way - common preaching techniques in the seventeenth century (Ibid., v. I, p. 88). ${ }^{15}$

Again, his attention to the use of justice in his territory and the policy of teaching as one of the main instruments of his ruling over Braga would be in vain without an effort to raise and ordain a better clergy - better in education and behavior. Sousa indicated how the Archbishop did not allow the nomination of clergymen due to requests of nobility and secular authorities, like when he refused the Queen Regent Catarina's request to give D. Antônio de Meneses the church of Santa Maria de Riba d'Ancora, knowing he would be an absent minister (ANTT, Gav. 19, m. 8, n. 24). Sousa also emphasizes the effort to amend the sinners among the clergy, recalling his letter from Trent to his right hand in Braga João de Leiria advising him to pay special attention to those and correct their sins of luxury, pomp and vanity (SOUSA, 1946, p. 218).

The difference between the goals of the two treatises analyzed in this paper clearly surfaces in the importance given to a central episode of the Archbishop's trajectory. While his participation in the Council of Trent was barely discussed by

\footnotetext{
${ }^{14}$ Foucault describes that as the pastor's paradox. (2008, pp. 172-173).

${ }^{15}$ An interesting analysis of the baroque preaching can be found in Federico Palomo's study about the the Society of Jesus in Portugal (2003).
} 
Granada, Sousa gave great attention to the matter. The long debate over the obligation to reside and the discussion about the nature of episcopal power - about whether it was of divine right, granted directly by God, or given by the Pope as an intermediate - was an irresolvable problem for more than a year, nearly paralyzing the Council. The ius divinum dispute was more than a simple theological debate. Establishing that expression on the decrees meant, according to its opposers, questioning the Pope's superiority to the bishops and jurisdiction over the bishoprics and their people by granting the prelates the sovereignty that came with the statement of the divine origin of their power. Besides, the reinforcement of the obligation of residence would harm the privileges of Cardinals and Curia officers who held benefices but lived in Rome. Bartolomeu dos Mártires was not only part but one of the heads of the group that pressured to secure the expression of the ius divinum on the decrees and insisted both on positive measures to guarantee discipline, a better behavior and a good education for the clergy as well as on a spiritual and theological outline of the episcopate, as an inspiration for pastoral office.

His leadership in the debates to increase the episcopal authority collided with the chronicler's intent to depict the Archbishop as clergyman aware of his place in hierarchy. The exception was his claim for the Primacy of Spain, placed in the treatise as a political plea, but always to honor Braga's Church - a celebration of portuguese pride (Ibid, v. III, pp. 104-111). Thus, the narrative about his attitude in Trent is rather ambiguous and the conflict with the Pope was silenced.

The first mention to the subject indicated an opposition to the discussion. During one of his speeches, he would have complained about the loss of time the debate on the nature and origin of episcopal power represented, claiming it did not help establishing measures for those who disobeyed the obligation of residence, and directing the focus to a disciplinary solution (Ibid., v. I, p. 222). A few pages after that, Sousa brought the Archbishop closer to the curial group by stating he claimed the debate about the ius divinum was a delay that did not proceed but dragged the 
solution for the matter (Ibid., v. I, p. 235). But those initial statements are contradicted by a quote of supposed speeches in which Bartolomeu dos Mártires would have claimed for a decision on the origin of episcopal power as essential to the problem of absenteeism (Ibid., v. I, pp. 237, 243) - an image that matches his speeches. ${ }^{16}$ Nevertheless, when dealing with the approval of the decrees, Sousa did not offer any information on its content regarding the ius divinum and even suggested the decision was a peaceful consensus (SOUSA, 1946, v. I, p. 245) - what could not be further from the actual quarrel between the curial and the reform parties that survived until the very end. ${ }^{17}$

But more importantly, besides having tried to hide the fact that the dominican was one of the leaders of the claim for the ius divinum, Sousa suppressed the debate constituted a political and hierarchical conflict of authority. By emphasizing his insistence on a disciplinary solution for establishing the need for personal residence, the chronicler echoed the archetype of pastorate funded in Trent, but neglected its main characteristics, the affirmation of episcopal power was almost excluded from the narrative. His part in the dispute against the Pontiff and the Curia seems forgotten in the pages Sousa deals with his warm reception in Rome, where he got close to Pius IV and was granted a series of privileges, as the right for absolution in reserved cases and a jubilee for his diocesans (Ibid., v. I, pp. 313-319).

Quite similar to Sousa's approach to Bartolomeu dos Mártires' attitude in the Council was his narrative about the problems the Archbishop faced with the Cathedral Chapter regarding the implementation of the tridentine decrees in Braga. As already mentioned above, the Provincial Council turned into a battlefield. Representatives of the Chapter made public complaints about the way the decrees were discussed and approved, the Archbishop's visiting policy and the severity of the decrees, refusing to abandon part of their benefits, besides accusing the prelate of summoning the Inquisition to deal with them (ADB, Gaveta dos Concílios e Sínodos,

\footnotetext{
${ }^{16}$ The Archbishop of Zara Muzio Callini made insteresting comments about his sppeches (ASV, Conc. Trid., 70, passim).

${ }^{17}$ Letter from the Archbishop of Zara to Cardinal Cornaro. Trent, June $12^{\text {th }} 1563$ (ASV, Conc. Trid., 69, ff. 156-157v).
} 
15). The struggle was latent and the Archbishop's attempt to use the Holy Office Tribunal as an upper hand only created more anger. The inquisitorial threat softened the conflict for a while; after Pedro Álvares de Paredes inquired specifically about sins against the Council of Trent during the beginning of $1565,{ }^{18}$ formal complaints ceased for some months, but the Provincial Council brought the issues back with full strength and the dispute changed to a new field. Both the Archbishop and the Cathedral Chapter, in agreement with the the sufragane Chapters (Coimbra, Porto and Viseu), sent their representatives to Rome in order to discuss the validity of the Provincial decrees, a fight that lasted until 1571 with a partial defeat for the Archbishop, the moderation of some important resolutions, in spite of his financial and diplomatic efforts (ASV, Congr. Concilio, Libri. Litter., 1, ff. 415-416). Nevertheless, according to Sousa, Dos Mártires would have made an effort to moderate the severity of the decrees appealing to the Holy See and tried to use his connections in Rome to help the local and cathedral clergy (SOUSA, 1946, v.. II, pp. 56-59). Although stating that some argued how that attitude was an attempt to made the clergy think he was not responsible for the decrees or a strategy to exercise a ruthless vigilance after the approval of the moderated rules, Sousa states his disagreement, adding that even though he wanted to be respected as their superior, the Archbishop did not care for public esteem and tried to soften the provincial decrees for thinking they were indeed "unworthy and harsh" and believing in the decency of the cathedral clergyman (Ibid., v. II, pp. 147-15). However, the chronicler admits there was a struggle in Rome regarding the approval of the initial text due to the action of the Crown and Chapters representatives, but connects Bartolomeu dos Mártires' displease to the delay in the final decision (1571) and the nomination of the Bishop of Cambrai as moderator of the cause (Ibid., v. II, pp. 159-164). ${ }^{19}$

A glimpse of the turbulent relations between the Archbishop and the other authorities from within Braga's territory can be found in the chapters in which Sousa deals with the Archbishop's pastoral visits. Besides attempting to the trouble caused

\footnotetext{
${ }^{18}$ All the records of the visitation were published (Liuro da visitação..., 1974).

${ }^{19}$ For more information on the conflict between bishops and the cathedral clergy in Portugal after the Council of Trent, see: SILVA, 2013.
} 
by the tradition of the responsible for the visits to the city's churches being chosen by the Chapter - emphasizing however how that custom jeopardized the bond between pastor and flock and how it went against the new tridentine canon about the bishops' rights/duties to visit any church within their territories instead of the long dispute between the parties regarding visitation rights that even after three concords was not entirely solved (ANTT, Cabido da Sé de Braga, Livro 1) - the chronicler commented on Bartolomeu dos Mártires' quarrels with military Orders and the Viscount of Ponte de Lima.

His confiscation of the incomes of the Order of Malta and the Order of Christ in order to reform and adorn their churches raised all kinds of censures, libels and excommunications from apostolic judges and secular tribunals - most of the causes answered to the Bishop of Angra and Açores, D. Manuel Almada, Commander of the Orders. But the papal Brief received in Rome exempted Bartolomeu dos Mártires from any kind of censure and reinforced the attitude of securing his jurisdiction. A litigation moved by the desire of securing the salvation of his sheep (SOUSA, 1946, v. II, pp. 83-96). The confiscation of the incomes of a church that belonged to the Order of Malta in Poiares caused the rage of its bailiff, who, along with a cavalry, summoned the dominican from his chambers. A serious issue solved in the narrative by the Archbishop's severe words, arousing the light of redemption in his heart (Ibid., v. II, pp. 131-133).

Sousa mentioned the Viscount of Ponte de Lima as one of the biggest opposers of the dominican. But added how he was converted by the Archbishop's devotion and mercy and grew a great respect for him (Ibid., v. II, p. 96). He failed to mention the Viscount was the leader of the riot in favor of D. Antônio that tried to kill the prelate when he did not choose his former student as king in 1580. The threat of death certainly stimulated his option for the Habsburg and his escape for Tui (Archivo General de Simancas, EST., LEG., 412, 235). 
The Archbishop's will to affirm his jurisdiction over the diocesans lead to conflicts with Crown's and noble's representatives, as the rage of a local judge when amended for the sin of being amused, or the dispute with the ombudsman of Chaves about his attempt to arrest a criminal hidden in a church. In Sousas's narrative, the reason for the prelate's interference was the depredation of the church. Although admitting conflicts with secular authorities were common, he explained it with the Archbishop's desire to maintain ecclesiastical immunity, meanwhile the evidences point to an interference in all kinds of justice - both religious and secular (SOUSA, 1946, v. II, pp. 104-106; ADB, Coleção Cronológica, 1846-1849, 1887).

The narrative about the regal inquiry lead by Pedro da Cunha in the north of the Realm also emphasizes the conflict between the prelate and the Crown. Sousa recognizes the Archbishop's protest to King Sebastian was an expression of his dislike to the loss of power the entry of Cunha in his territory represented. He fought for the maintenance of the privilege of supreme jurisdiction over his lands, enjoyed by his predecessors and respected by previous kings (SOUSA, 1946, v. II, pp. 201202).

It seems Sousa's inclination to discuss the squabbles that involved the Archbishop regarded solely the conflicts with military Orders or Crown representatives. His problems with the local clergy or other religious authorities, as the divergence with the Roman Curia and the Papacy during the Council of Trent or the endless litigation against the Cathedral Chapter were minimized or even silenced. And the few words dedicated to those conflicts modify his attitude towards those who he saw as enemies, as if they acted with great respect among each other. A good example is the description of the supposed encounter with Felipe II on his way from Trent back to Braga, during which he would have refused to call the King "majesty", claiming a reverence to a mundane majesty would offend God, the only true prince (Ibid., v. II, p. 33). Of course his displease with the King could be explained by the monarch's rage against the Archbishop, due to his attempt to approve Carranza's Catechism in the Index Congregation. Felipe II pressed his 
ambassadors for a severe punishment that never came (RAH, Processo Carranza, XVII, f. 25). But obviously Sousa could not indicate the existence of a conflict and explain how Bartolomeu dos Mártires plotted with a few to maneuver the Congregation's rules and declare the book free of suspicious (ACDF, St., St., R1 (e), ff. 562v-563). A great disrespect to the Council like that should remain hidden. Good government should not include abysses inside the ecclesiastical body. The search for common good implied harmony and respect to hierarchy. The status of saint should not be granted for those who defied Rome and fought against their biggest collaborators in the maintenance of the miter and the guidance of God's sheep. However, the battle against mundane authorities who got in the Archbishop's way to fulfill his obligations and take good care of his flock by watching them close and providing for all their spiritual and material needs was a noble one, worthy of a saint. His quest to ensure his own power and jurisdiction over the diocesans and ecclesiastical body of Braga's Church and the statement about how the Church Reform should be conducted by the episcopate as the major authority on any matter lost any political content, becoming a tale of devotion to a sacred mission, filled with sense of obligation, mercy and respect for those who opposed him or his Reformation policy - a will to change instead of fighting them. A tendency for correction that went further the common amendment of sins.

A particularly delicate subject was Bartolomeu dos Mártires' adherence to the Habsburg domination. Of course, when the treatise was written, Portugal remained under the domain of the Philips and Sousa should not express any suspect of infidelity to the Crown, in spite of his previous display of animosity when he set fire to his family home. Some parts, especially those regarding the arguments of those in favor of D. Antônio, could be interpreted as hints of an inclination for the internal party. According to Sousa, the Archbishop recommended following the Governors left by Cardinal Henrique and the fidelity of the good christians who declared they would follow only whomever the Archbishop chose as king was essential for the failure of D. Antônio's supporters. The chronicler then mentioned an election summoned by Dos Mártires that followed the escape of the Governors, for which 
there are no evidences. Sousa's words about the love of the master for the disciple and his fear for the common good are some other clues of the author's positioning. The decision to pledge fidelity to Spain was, in Sousa's narrative, left to the people, and not a choice between peace and war against the spanish troops (SOUSA, 1946, v. 2, pp. 264-270). Once again, his political actions were silenced by Sousa.

\section{The canonization process}

The Order's effort to praise Bartolomeu dos Mártires as a saint was successful. More than a century latter, Sousa's piece would become the basis for part of the process. Almost a decade after Sousa's hagiography was print, the Congregation of Rites began the procedures to analyze his beatification and canonization process in 1631, under the initiative of D. Rodrigo da Cunha, Archbishop of Braga, who developed an expressive propaganda program to praise and publicize the glories of his Archdiocese, of which is a good example his treatise about the renowned prelates who ruled the Primate See (CUNHA, 1634-1635). The protagonism of the Order was manifested on the records of the second phase of the process, the 1702-1704 noncultu and 'life and miracle' inquiries, initiated by the Archbishop upon request of the Viana Monastery’s Prior (ASV, Congr. Riti, Processus, 292, 295). But canonizing the dominican would be an undertaking that would drag itself for centuries. The last inquiries of the process by the Congregation of Rites date from 1766 and its conclusions are yet to come - up until recently, the Archbishop was granted beatification, but remained a miracle away from achieving sainthood until Pope Francis agreed to equipollent canonization.

These first inquiries (1631-1635, ordinary informative inquiries in Braga and Viana) (ASV, Congr. Riti, Processus, 291, 293) focused on the Archbishop's personal characteristics and his dedication to the diocesans, a reflection of Granada's and Sousa's treatises' highlights - a similarity with the canonization process of the Archbishop of Milan Carlo Borromeo, a partner of the portuguese in the battle for the implementation of the Tridentine Reformation. The debate about Borromeo's 
canonization in the Congregation of Rites began in 1604 and, according to Giuseppe Alberigo (1967), focused on his personal characteristics, leaving his achievements as Archbishop aside. The construction of his sanctified profile hid his conflicts with the clergy and the secular authorities in Milan. His use of the authority granted by the miter as a political instrument led to intense debates in the Congregazione dei Beati (GOTOR, 2002, pp. 68-69). Some considered his ruling over the Archdiocese represented an unbalance between episcopal and papal/curial power, and that could not be part of his holy image.

The Barefoot Carmelites were responsible for these first inquiries. Leaving politics aside, the questions were based on the theological and cardinal virtues, his devotion and respect for sacred images, relics and traditional rites, his humbleness, self-penance, patience and resilience. It is curious to notice how the dedication to the obligations of office - something that could be considered the most outstanding characteristic of his life, the major reason for his fame - constituted a single question among nineteen. His actions as ruler of Braga and the power episcopal office brought him were discussed as an obstacle for his modesty. The conflicts with secular or local authorities were not mentioned. The miracles were the subject of only one question as well. The obedience to the Roman Church, his confessors and superiors was clearly stated in one of the first questions (ASV, Congr. Riti, Processus, 291, 293).

Thus, the beginning of the attempt to make him a saint followed the same pattern: sanctity was expressed by personal characteristics and respect for ecclesiastical authority - what distinguished those blessed with holiness from common man came from within more than from deeds. An interesting contradiction to the tridentine statement about the relevance of deeds for salvation.

One of the latest parts of the canonization process, however, went on a different direction. Written in 1766 by Vicente Lupinacer, the Provincial of the Order in Portugal, the piece is based on Sousa's hagiography, but in several points indicates Dos Mártires' combative attitude, highlighting his conflicts with the local nobility 
and clergy. As a proposal for his beatification/canonization, the piece focused on key points of an hagiography, as the practice of charity, his dedication to the care of the diocesans, the pastoral visits and the merciful surveillance of religious offenses, but it also showed his fight for authority and how he faced those who crossed what he believed was his jurisdiction. The attempt to turn the Archbishop into a saint did not hide his political feature, although presenting it as a defense of ecclesiastical power and episcopal dignity:

A very convincing argument of the honorable Servant of the Lord's heroic faith was the zeal, and the courage he always showed defending the ecclesiastical immunity and the rights of his episcopal dignity, not caring about human relations, but with apostolical heart, going against the insults and mistreatments, despising threats and dangers, and sustaining long and very expensive litigation in regal courts to which he was summoned by his enemies and contradictors, declaring openly and with apostolical freedom in front of the judges of those Tribunals and even the King that Your Majesty should let him keep and preserve completely the ecclesiastical immunity he solemnly swore to keep and preserve, or appoint someone else to the office [...] (ASV, Congr. Riti, Processus, 298).20

The piece states the military Orders were some of the biggest enemies of the Archbishop, especially the Order of Malta, as previously mentioned by Sousa. Nevertheless, Lupinacer's words give a better idea of how intense was the conflict, indicating the amount of formal complaints moved by the Order's curator in secular courts (AGOP, Series X, 45.9, f. 54-55). Likewise, Bartolomeu dos Mártires' conflicts against the Viscount of Ponte de Lima were discussed with much more detail and there is a better indication of the intensity of their enmity due to disagreements about the Archbishop's rights to visit his lands, although the document does not mention the Viscount's role in the 1580 upraise that wanted to kill the Archbishop. According to the document, the animosity vanished little by little due to Dos Mártires effort. A saint could not die with enemies (Ibid., ff. 55v-56, 186v-187).

In addition to dealing with the prelate's quarrels with secular authorities and leaders, the piece indicated some of the battles against the clergy as well. The

\footnotetext{
${ }^{20}$ I quote from a copy of the piece located in the Order's archive: AGOP, Series X, 45.9, f. 53 (our translation).
} 
extremely long dispute with the cathedral clergy was given its proper magnitude. The plea regarding the tridentine and provincial decrees was described as a long struggle the cathedral clergy prepared for, joining forces with the clergy of subordinate dioceses and turning to the Crown for help. The episcopal right of visitation and the clergymen's flaws and offenses were also mentioned. Yet, following Sousa's lead, Lupinacer maintained the idea of the Archbishop turning to Rome in an attempt to minimize the damages of his clergy (Ibid., f. 74, 174-174v, 188-188v). The quarrel about those below him in hierarchy was fairly described. But the estrangement with the Roman Curia and the Papacy about the ius divinum and the tridentine intense debates were once more conveniently forgotten.

The Archbishop's desire to have control over his territory and diocesans, above other jurisdictions, can be inferred from the parts that describe his ruling over the city's courts. He wanted to rule over all kinds of matters, not only religious, but also civil and criminal, a prerrogative he believed was granted centuries ago to Braga's Church - once more, the basis of his claim against Pedro da Cunha's comitee (Ibid., f. 192). The Archbishop intended to act as a governor, and this part of his beatification and canonization process did not hide it. A subtle change of perception about what was allowed in a saint's profile. A perfect mix of a dedicated guide to his flock and a combative politician who wanted to ensure and guard his jurisdiction, as an instrument to fulfill his obligations to his people. And it was precisely that what made him an example. The pastor made room for the politician.

\section{Concluding remarks}

The sanctification of the Archbishop of Braga was a long term project, that suffered a significant change in the eighteenth century. The Order's effort to promote him as a saint lead by Luis de Sousa made a good use of Granada's perspective of Dos Mártires as an example of the archetype for the episcopate raised in the Council of Trent, leaving aside his confrere's appeal to a spirituality that became one of the most controversial theological tendencies of the sixteenth century. Nevertheless, one of 
the biggest characteristic of the dominican's ruling over Braga remained in silence. His political and hierarchical conflicts were almost neglected, unless those that indicated the demarcation of the Archbishop's superiority to the secular power never indicated as part of a bigger scenario, that of the tridentine episcopate's fight for authority. Only the last pieces of his beatification and canonization process offered a glimpse of that issue.

The official recognition of his sanctity would come even latter: in 1845 he was declared Venerable by Gregory XVI and in 2001 Pope John Paul II recognized one miracle necessary for his beatification. The lack of other miracles, however, prevented the process from moving forward. Only recently his canonization became possible, after january $20^{\text {th }}$ 2017, when Pope Francis allowed the Congregation for the Causes of Saints (the new Congregation of Rites) to go forward with the equipollent canonization, which means the exemption of another comprobable miracle, a resource used by the Church (and especially by Pope Francis), to drag the attention to a certain way of living, to a model of service to the Church and its congregation. Of course the process is not finished yet, but now the major obstruction to his canonization has been surpassed and soon he'll will join the role of saints. Bartolomeu dos Mártires' devotion to his obligations as a clergyman and an Archbishop, his sacrifice to be close to his people and bring them to the Church' core, creating the sense of a strong and unbreakable community, and his disposition to fight for the lost sheep and bring them back to the flock reflect Francis' attempt to reconnect people to the Church. In face of the great losses to new and reformulated christian agendas during the last decades, which demanded not only a more progressive position regarding polemic topics and a tougher attitude upon the clergy's behavior after severe scandals Benedictus XVI mismanaged, the idea of presence and proximity between the clergy and the assembly became more important. The Pope's program refers to the ideia of the bishops (and also the clergy) as pastors, and deepen its roots in the tridentine model as well as in the primitive christianity, in which Bartolomeu dos Mártires sought for parameters. In times of crises, the cycle always goes back to a magical primitive beginning, a time of devoted 
pastors, and exalts the memory of role models that offer inspiration. And few could be as useful as a model for Pope Francis as the Archbishop of Braga, who lived a life dedicated to reforming his Church and people, and keeping them together in the path towards salvation.

\section{REFERENCES}

ALBERIGO, G. Carlo Borromeo come modello di vescovo nella Chiesa post-tridentina. Rivista Storica Italiana, v. LXXIX, pp. 1031-1052, 1967.

ALBERIGO, G. L'istituzione e i poteri nella Chiesa. L'Episcopato nel cattolicesimo riformato xvi-xvii secoli.. VOGLER, B. (ed.). Miscellanea Historiae Ecclesiasticae. L'Institution et le pouvoir dans les Eglises de l'antiquité à nos jours. Bruxelas; Louvain, n. VIII , pp. 268-286, 1987.

Archivio della Congregazione per la Dottrina della Fede, St.,St., R1 (e).

Archivio Segreto Vaticano, Conc. Trid., 42.

Archivio Segreto Vaticano, Conc. Trid., 69.

Archivio Segreto Vaticano, Conc. Trid., 70.

Archivio Segreto Vaticano, Congr. Concilio, Libri. Litter., 1.

Archivio Segreto Vaticano, Congr. Riti, Processus, 291, 293.

Archivio Segreto Vaticano, Congr. Riti, Processus, 292, 295.

Archivo General de Simancas, EST., LEG., 412, 235.

Archivum Generalis Ordinis Praedicatorum, Series X, 45.9.

Archivum Romanum Societatis Iesu, Antica Compagnia, Assistentia Lusitaniae, Lusitania, 63.

Arquivo Distrital de Braga, Coleção Cronológica, 1941.

Arquivo Distrital de Braga, Gaveta de Concílios e Sínodos: 6, 8, 9, 10, 11, 12, 14, 15, 16, 17 , 19, 20, 21, 22; Gaveta das Concórdias e Visitas: 25, 26, 27, 29, 29, 30,31, 32, 33, 34, 35, 36, $38,39,42,43,45,46,49,51,5254$ 58, 81, 110.

Arquivo Distrital de Braga, Visitas e devassas, 47-7; 435-2. 
Arquivo Nacional da Torre do Tombo, Cabido da Sé de Braga, Livro 1

Arquivo Nacional da Torre do Tombo, Gav. 19, m. 8, n. 24.

CUNHA, R. Historia ecclesiastica dos arcebispos de Braga, e dos Santos, e varoes illustres, que florecerão neste arcebispado. Braga: Manoel Cardoso, 1634635.

FOUCAULT, M. Segurança, território, população. São Paulo: Martins Fontes, 2008.

GOTOR, M. I beati del papa. Santità, Inquisizione e obbedienza in età moderna. Firenze: Leo Olschki, 2002.

GOUVEIA, A. Contra-Reforma. In: AZEVEDO, C. Dicionário de História Religiosa de Portugal. Lisboa: Círculo de Leitores, 2000. pp. 15-19.

GRANADA, L. De officiis et moribus episcoporum [1565]. In: Fray Luis De Granada. Obras Completas. [s/l]: F.U.E., 1999, t. XV.

GRANADA, L. Vida de Don Fr. Bartolomé de los Mártires, Arzobispo de Braga [1615]. In: Obras Completas. Madrid: Fundación Universitaria Española Dominicos de Andalucía, 1997 , t. XVI.

LIURO DA VISITAÇÃO que se [a Inquisição] fez na Cydade de Braga e seu Arcebispado [1565]. Porto: Arquivo Histórico Dominicano Português-Movimento Bartolomeano, 1974.

LOGAN, O. The Venetian upper clergy in the 16th and early 17th centuries: a study in religious culture. Salzburg: Institut fur Anglistik und Amerikanist / Universitat Salzburg, 1995, 2vv..

MARCOCCI, G. O arcebispo de Braga, D. Frei Bartolomeu dos Mártires (1552-1582). Um caso de inquisição pastoral? Revista de História da Sociedade e da Cultura.

Coimbra: Palmage, n. 9, pp. 119-146, 2009.

MÁRTIRES, B. Catecismo ou Doutrina Cristã e Práticas Espirituais [1564]. Porto: Movimento Bartolomeano, 1962.

MÁRTIRES, B. Compêndio de doutrina espiritual [1582]. Lisboa, 2000.

MÁRTIRES, B. Estímulo de Pastores [1565]. Porto: Movimento Bartolomeano, 1981.

PAIVA, J. P. Os Bispos de Portugal e do Império. 1495-1777. Coimbra: Imprensa da Universidade de Coimbra, 2006.

PALOMO, F. Fazer dos campos escolas excelentes: os jesuítas de Évora e as missões do interior em Portugal (1551-1630). [s/l]: Fundação Calouste Gulbenkian; Fundação para a Ciência e a Tecnologia, 2003. 
PALOMO, F. A Contra-Reforma em Portugal (1540-1700). Viseu: Livros Horizonte, 2006.

PASTORE, S. Una herejía española: conversos, alumbrados e Inquisición (1449-1559). Madrid: Marcial Pons, 2010.

PEREIRA, J. Um Arcebispo em defesa do poder episcopal: as relações entre D. Frei Bartolmeu dos Mártires e o Santo Ofício português (1559-1582). São Paulo, 2017, 334f.

Tese (Doutorado em História) - Faculdade de Filosofia, Letras e Ciências Humanas, Universidade de São Paulo.

POLÓNIA, A. D. Henrique: o Cardeal-Rei. Lisboa: Círculo de Leitores, 2005.

Real Acdemia de la Historia, Processo Carranza, XVII, f. 25.

SILVA, H. O clero catedralício português e os equilíbrios sociais do poder (1564-1670). Lisboa: Centro de Estudos de História Religiosa, 2013.

SOUSA, L. Vida de Dom Frei Bartolomeu dos Mártires [1619]. Lisboa: Sá da Costa, $1946,3 \mathrm{~V}$. 